\title{
Antagonists for the human oxytocin receptor: an in vitro study
}

\author{
M. Maggi ${ }^{1}$, G. Fantoni ${ }^{1}$, E. Baldi ${ }^{1}$, A. Cioni ${ }^{1}$, S. Rossi ${ }^{1}$, \\ G. B. Vannelli ${ }^{2}$, P. Melin ${ }^{3}$, M. Åkerlund ${ }^{4}$ and M. Serio ${ }^{1}$ \\ ${ }^{1}$ Department of Clinical Physiopathology, Endocrinology Unit; and ${ }^{2}$ Department of Human Anatomy and \\ Histology, University of Florence, 50134 Florence, Italy; ${ }^{3}$ Research Department, Ferring Pharmaceuticals, \\ Malmö, Sweden; and ${ }^{4}$ Department of Obstetrics and Gynecology, University Hospital, Lund, Sweden
}

The oxytocin antagonist $\left[\mathrm{Mpa}^{1}, \mathrm{D}-\mathrm{Tyr}(\mathrm{Et})^{2}, \mathrm{Thr}^{4}, \mathrm{Orn}^{8}\right]$-oxytocin has been successfully used for treating premature labour. The interactions of this antagonist with neurohypophysialhormone receptors in the human myometrium were investigated. Competition curves among $\left[{ }^{3} \mathrm{H}\right]$ oxytocin, $\left[{ }^{3} \mathrm{H}\right]$ arginine vasopressin, $\left[{ }^{3} \mathrm{H}\right][1-(\beta$-mercapto- $\beta, \beta$ cyclopentamethylenepropionic acid)2-(O-methyl)-tyrosine, 8-arginine] vasopressin, the corresponding unlabelled peptides and a series of oxytocin antagonists including $\left[\mathrm{Mpa}^{\mathrm{I}}{ }^{\mathrm{D}} \mathrm{D}-\right.$ $\operatorname{Tyr}(\mathrm{Et})^{2}, \mathrm{Thr}^{4}, \mathrm{Orn}^{8}$ ]-oxytocin were constructed from results taken from the myometrium of pregnant women and rabbits, and were analysed simultaneously using the computer program LIGAND. The biological activity of $\left[\mathrm{Mpa}^{1}, \mathrm{D}-\mathrm{Tyr}(\mathrm{Et})^{2}, \mathrm{Thr}^{4}, \mathrm{Orn}^{8}\right]$-oxytocin in the human uterus was investigated by studying its effect on oxytocin-induced intracellular $\mathrm{Ca}^{2+}$ mobilization in human myometrial cells in culture that were expressing high concentrations of oxytocin receptors. The results indicate that $\left[\mathrm{Mpa}^{1}, \mathrm{D}-\mathrm{Tyr}(\mathrm{Et})^{2}, \mathrm{Thr}^{4}, \mathrm{Om}^{8}\right]$-oxytocin and related antagonists are selective for the oxytocin receptor in the myometrium of pregnant rabbits but not of pregnant women. In women, they bind with high affinity to the VI vasopressin receptor. In myometrial cells $\left[\mathrm{Mpa}^{\mathrm{I}}, \mathrm{D}-\mathrm{Tyr}(\mathrm{Et})^{2}, \mathrm{Thr}^{4}, \mathrm{Or}^{8}\right]$-oxytocin inhibits the oxytocin-induced increase in intracellular $\mathrm{Ca}^{2+}$ concentration in a dose-dependent fashion, with an $\mathrm{IC}_{50}$ value of $5 \mathrm{nmol} \mathrm{I}^{-1}$. The uterine relaxant effect of this antagonist might result not only from the block of the oxytocin receptor, but also from interaction with the VI vasopressin receptor.

\section{Introduction}

In pregnant females at term, oxytocin signalling in the uterus is upregulated. The increase in oxytocin-mediated events is believed to be responsible for the onset of coordinated and forceful contractions that lead to the expulsion of the conceptus. However, the molecular mechanisms underlying oxytocininduced uterine hyperactivity are still unclear. An increase in the circulating concentration of oxytocin, uterine responsiveness to oxytocin (Fuchs and Fuchs, 1984; Casey and MacDonald, 1988; Leake, 1990; Steer, 1990) and the synthesis of oxytocin in the uterus (Ciarochi et al., 1985; Lefebvre et al., 1992) have been suggested to be involved.

In any case, the activation of the uterine oxytocin receptor is an obligate step for oxytocin-induced activation of cells in the uterus. Hence, the more rational approach to treating premature labour is the downregulation or blockade of the oxytocin receptor. From animal studies, the only factor known to downregulate the uterine expression of the oxytocin receptor is progesterone (Soloff, 1975; Nissenson et al., 1978; Hixon and Flint, 1987). However, this steroid has been shown to be ineffective in preventing premature labour in humans (Fuchs and Stakemann, 1960). Furthermore, proges-

Received 14 October 1993. terone apparently does not inhibit the expression of the oxytocin receptor in humans (Maggi et al., 1992). Recent studies have, therefore, focused on the development of oxytocin receptor antagonists, a whole series of which have been synthesized during the past 20 years (Sawyer and Manning, 1989).

One of these antagonists, $\left[\mathrm{Mpa}^{1}, \mathrm{D}-\mathrm{Tyr}(\mathrm{Et})^{2}, \mathrm{Thr}^{4}, \mathrm{Om}^{8}{ }^{8}\right.$ oxytocin (dETVT; also known as ORF 22164, RWJ 22164 or Atosiban), has been used successfully in clinical pilot studies to treat pre-term labour in women (Akerlund et al., 1987; Andersen et al., 1987); this antagonist inhibited uterine contractions in all (Akerlund et al., 1987) or in the majority (Andersen et al., 1987) of the patients studied. Although dETVT binds with high affinity (Fuchs $e$ t al., 1987) and selectivity (Pettibone et al., 1992) to the oxytocin receptor in the rodent uterus, it has 10 times less affinity for the oxytocin receptor than has oxytocin in the human myometrium (Fuchs et al., 1987). Furthermore, in the human uterus and liver, dETVT binds with high affinity to the VI vasopressin receptor (Pettibone et al., 1992).

Since both oxytocin receptors and VI vasopressin receptors are present in the rabbit (Maggi et al., 1988b, 1991a) and human (Maggi et al., 1990, 1992) uterus, the ligand selectivity of dETVT was compared in membranes prepared from the myometrium of pregnant rabbits and women at term. In addition, the antagonistic properties of dETVT were 
investigated on oxytocin-induced $\mathrm{Ca}^{2+}$ mobilization in oxytocin-receptor-positive human myometrial cells.

\section{Materials and Methods}

\section{Chemicals}

$\left.\mathrm{d}\left(\mathrm{CH}_{2}\right)_{5}\left[\mathrm{Tyr}(\mathrm{Me})^{2}, \mathrm{Thr}^{4}, \mathrm{Om}^{8},\left[^{125}\right]\right] \mathrm{Tyr}^{9}-\mathrm{NH}_{2}\right]$-vasotocin $\left({ }^{125} \mathrm{I}\right]$ OTA; $\left.2200 \mathrm{Ci} \mathrm{mmol}^{-1}\right),\left[{ }^{3} \mathrm{H}\right]$ oxytocin $\left(\left[{ }^{3} \mathrm{H}\right] \mathrm{OT} ; 36 \mathrm{Ci} \mathrm{mmol}^{-1}\right)$, $\left[{ }^{3} \mathrm{H}\right]$ arginine vasopressin $\left(\left[{ }^{3} \mathrm{H}\right] \mathrm{AVP} ; 70 \mathrm{Ci} \mathrm{mmol}{ }^{-1}\right)$ and $\left[{ }^{3} \mathrm{H}\right]$ [1-( $\beta$-mercapto- $\beta, \beta$-cyclopentamethylenepropionic acid)2- $-(\mathrm{O}$ methyl)-tyrosine, 8-arginine]vasopressin $\left({ }^{3} \mathrm{H}\right] \mathrm{d}\left(\mathrm{CH}_{2}\right)_{5} \mathrm{Tyr}$ MeAVP; $50 \mathrm{Ci} \mathrm{mmol}^{-1}$ ) were purchased from New England Nuclear (Boston, MA). The tritiated ligands were divided into aliquots in plastic tubes, sealed under nitrogen, and frozen at $-80^{\circ} \mathrm{C}$. Arginine vasopressin, oxytocin and the rabbit polyclonal antibodies to human desmin were purchased from Sigma Chemical Co. (St Louis, MO). OTA and $\mathrm{d}\left(\mathrm{CH}_{2}\right)_{5}$ TyrMeAVP were obtained from Peninsula Laboratories, Inc (San Carlos, CA). dETVT, desGly ${ }^{9}\left[\mathrm{Mpa}^{1}, \mathrm{D}-\mathrm{Tyr}(\mathrm{Et})^{2}, \mathrm{Thr}^{4}\right.$, $\mathrm{Orn}^{8}$ ]-oxytocin (F123) and desGly $\left[\mathrm{D}-\mathrm{Tyr}(\mathrm{Et})^{2}, \mathrm{Thr}^{4}, \mathrm{Orn}^{8}\right]$ $\mathrm{dC6}$-oxytocin (F327) were generously provided by Ferring Pharmaceuticals, Malmö. The monoclonal antibody to human vimentin (clone V9) was purchased from Dako Corporation (Carpinteria, CA).

\section{Cells}

Hs 805.Ut (corpus uteri, normal, human) cells were obtained from the American Type Culture Collection (Rockville, MD; ATCC CRL 7795) and maintained in culture in Dulbecco's modified Eagle's medium, supplemented with $10 \%$ fetal calf serum and antibiotics.

Uteri in the early follicular or late luteal phase of the menstrual cycle were taken from two women with a normal menstrual cycle (but who were undergoing hysterectomy for gynaecological reasons), since high densities of oxytocin receptors are present at these times (Maggi et al., 1992) [patient 1 (M1): 40 years old, early follicular phase; patient 2 (M2): 49 years old, late luteal phase].

Myometrial cells were prepared as previously described (Maggi et al., 1991b). Briefly, $1 \mathrm{mg}$ collagenase solution $\mathrm{ml}^{-1}$ (Type IV) was added to the finely minced stripped uterine tissue for $12 \mathrm{~h}$ at $37^{\circ} \mathrm{C}$. Digested fragments were then washed twice in Hanks' balanced salt solution, mechanically dispersed and plated in $25 \mathrm{~cm}^{3}$ flasks in Coon's Modified Ham's FI2 medium containing $10 \%$ fetal calf serum and antibiotics. Cultures were maintained in $5 \% \mathrm{CO}_{2}$ at $37^{\circ} \mathrm{C}$, refed three times a week, subcultured at confluence and used for up to 10 passages. Every serial passage of the sister cultures was frozen in culture medium supplemented with $10 \%$ dimethyl sulfoxide. The smooth muscle origin of the myometrial cells in culture was verified by immunofluorescence (see below) using anti-desmin and anti-vimentin antibodies according to Leoni et al. (1990), and by binding studies with the oxytocin antagonist (see below). [Desmin is a Type III intermediate filament, characteristic of muscle cells and absent in connective tissue, which has recently been shown to be extensively present in human uterine smooth muscle cells (Leoni et al. 1990).] Very low contamination $(<10 \%)$ with fibroblasts (desmin-negative; vimentine-positive) was observed.

In order to purify myometrial cells further, the cell culture from M1 was dilution-cloned at the third doubling. Cells were diluted $\left(2.5\right.$ cells ml $\left.^{-1}, 200 \mu \mathrm{l} \mathrm{well}^{-1}\right)$ directly into microwells in the presence of $10^{5}$ human peripheral mononuclear cells that had previously been irradiated with $6000 \mathrm{rad}$ (feeder cells). The clones were selected using immunofluorescence and binding studies. Strains found to be desmin-positive, vimentin-positive and oxytocin-receptor-positive were obtained, maintained as previously described and used for experiments up to 10 passages. The clone used in this study was called D6.

For immunofluorescence studies, human myometrial cells were grown on plastic coverslips (Aclar, Allied Engineered Plastic, Pottsville, PA) and fixed in $3.7 \%$ paraformaldehyde in PBS, $\mathrm{pH} \mathrm{7.4,} \mathrm{for} 10 \mathrm{~min}$ and for an additional $10 \mathrm{~min}$ in $0.1 \%$ Triton X-100. Afterwards, coverslips were washed in PBS and incubated for $90 \mathrm{~min}$ with anti-desmin and anti-vimentin antibodies (1:100). Incubation with the primary antibody was followed by incubation with fluorescein-coupled goat antirabbit IgG at a 1:200 dilution. The coverslips were examined and photographed using a Nikon MICROPHOT-FX microscope equipped with fluorescence filters (Nikon, Kogaku, Tokyo).

\section{Membrane preparation}

Human uterine specimens were collected at the time of caesarean section from ten patients who were delivered at an average time of gestation of $38 \pm 1$.I weeks. Patients undergoing caesarean section were informed of the study protocol and the procedures used to obtain samples. Uterine horns were also obtained from two pregnant New Zealand White rabbits on day 29 of gestation.

Membranes were prepared as described by Maggi et al. (1988b, 1990). Myometrial tissues were suspended in buffer I (10 mmol Tris- $\mathrm{HCl} \mathrm{l}^{-1}, \mathrm{pH} 7.4$, containing $1.5 \mathrm{mmol}$ EDTA $1^{-1}, 0.5 \mathrm{mmol}$ dithiothreitol $\mathrm{l}^{-1}, 1 \mathrm{mmol}$ benzamidine $1^{-1}, 0.01 \%$ bacitracin and $0.002 \%$ soybean trypsin inhibitor) and homogenized. The homogenate was centrifuged at $1000 \mathrm{~g}$ for $10 \mathrm{~min}$ at $4^{\circ} \mathrm{C}$. The supernatant containing the crude membrane fraction was then centrifuged at $160000 \mathrm{~g}$ for $30 \mathrm{~min}$ at $4^{\circ} \mathrm{C}$. The resulting pellets were washed once in buffer 2 (50 mmol Tris-maleate $1^{-1}, \mathrm{pH} 7.6,10 \mathrm{mmol} \mathrm{MgSO}_{4} \mathrm{I}^{-1}$, 1 mmol benzamidine $1^{-1}, 0.01 \%$ bacitracin, $0.002 \%$ soybean trypsin inhibitor) and centrifuged again at $160000 \mathrm{~g}$ for $30 \mathrm{~min}$ at $4^{\circ} \mathrm{C}$. The final pellets were then resuspended in buffer 2 and divided into small aliquots $(0.2 \mathrm{ml})$. Membrane preparations were frozen in solid $\mathrm{CO}_{2}$ and stored at $-80^{\circ} \mathrm{C}$ until assayed. Protein concentration was determined using the Bio-Rad protein assay kit (Bio-Rad Laboratories, Munich).

\section{Binding assays}

Binding studies for $\left[{ }^{3} \mathrm{H}\right]$ oxytocin, $\left[{ }^{3} \mathrm{H}\right] \mathrm{AVP}$, and $\left[{ }^{3} \mathrm{H}\right] \mathrm{d}\left(\mathrm{CH}_{2}\right)_{5}$ TyrMeAVP to human and rabbit myometrial membranes were performed as described by Maggi et al. (1988b, 1990). According to these studies, human myometrial membranes 
$\left(0.3 \mathrm{mg} \mathrm{ml}^{-1}\right)$ were incubated with ligands in buffer 2 in the presence of $0.1 \% \mathrm{BSA}$ at $22^{\circ} \mathrm{C}$ for $90 \mathrm{~min}$ for tubes containing $\left[{ }^{3} \mathrm{H}\right] \mathrm{AVP}$, for $60 \mathrm{~min}$ for tubes containing $\left[^{3} \mathrm{H}\right] \mathrm{d}\left(\mathrm{CH}_{2}\right)_{5}$ TyrMeAVP, and for $180 \mathrm{~min}$ for tubes containing $\left[{ }^{3} \mathrm{H}\right]$ oxytocin. Rabbit myometrial membranes were incubated as for human membranes but for different durations: $120 \mathrm{~min}$ for tubes containing $\left[{ }^{3} \mathrm{H}\right] \mathrm{AVP}, 90 \mathrm{~min}$ for tubes containing $\left[{ }^{3} \mathrm{H}\right] \mathrm{d}\left(\mathrm{CH}_{2}\right)_{5}$ TyrMeAVP, and $300 \mathrm{~min}$ for tubes containing $\left[{ }^{3} \mathrm{H}\right]$ oxytocin. $\left[{ }^{3} \mathrm{H}\right] \mathrm{AVP},\left[{ }^{3} \mathrm{H}\right] \mathrm{d}\left(\mathrm{CH}_{2}\right)_{5}$ TyrMeAVP and $\left[{ }^{3} \mathrm{H}\right]$ oxytocin were present at a concentration of $0.7 \mathrm{nmol}^{-1}$ in tubes containing increasing concentrations $\left(0.1-10000 \mathrm{nmol} \mathrm{l}^{-1}\right)$ of unlabelled peptides and at $0.03-0.7 \mathrm{nmol} \mathrm{l}^{-1}$ in tubes without unlabelled ligands (final volume: 0.25 and $0.5 \mathrm{ml}$ for human and rabbit membranes, respectively). All measurements were obtained in triplicate.

After incubation, membranes were filtered through Whatman GF/B filters (Clifton, NJ), which had been presoaked in ice-cold 50 mmol Tris $1^{-1}, \mathrm{pH} \mathrm{7.4,} \mathrm{in} 0.1 \% \mathrm{BSA}$, using the Brandel M-48R 48-well cell harvester (Gaithersburg, MD) or the Millipore 1225 Sampling Manifold (Bedford, MA). Filters were washed twice with $3 \mathrm{ml}$ ice-cold $50 \mathrm{mmol}$ Tris $1^{-1}$, $\mathrm{pH}$ 7.4, and placed in liquid scintillation vials. Filter-retained radioactivity was measured in a liquid scintillation counter, after overnight incubation in $10 \mathrm{ml}$ scintillation fluid (Instagel, Packard Instruments Company Inc, Downers Grove, IL).

Confluent $\left(20-70 \times 10^{3}\right)$ myometrial cells were washed twice with Dulbecco's modified Eagle's medium, $20 \mathrm{mmol}$ Hepes $\mathrm{l}^{-1}, 10 \mathrm{mmol} \mathrm{MgSO}_{4} \mathrm{l}^{-\mathrm{I}}, 0.5 \% \mathrm{BSA}, \mathrm{pH} \mathrm{7.4}$, and incubated in $200 \mu \mathrm{l}$ of the same binding medium at $22^{\circ} \mathrm{C}$ for $60 \mathrm{~min}$ with fixed concentrations (15-50 pmol $1^{-1}$ ) of $\left[{ }^{\mathrm{I} 25} \mathrm{I}\right] \mathrm{OTA}$ in the presence or absence of increasing concentrations of unlabelled ligands $\left(10^{-11}-10^{-7} \mathrm{~mol} \mathrm{l} \mathrm{l}^{-1}\right)$. After incubation, cells were extensively washed with ice-cold PBS, $0.1 \% \mathrm{BSA}$, solubilized in $0.5 \mathrm{~mol} \mathrm{NaOH}^{-1}$ and the cell-bound radioactivity was determined. Measurements were obtained in triplicate. Cell counts routinely varied by less than $10 \%$ between wells.

\section{Measurement of the intracellular $\left[\mathrm{Ca}^{2+}\right]$}

Myometrial cells were grown to confluence on plastic coverslips (Aclar, Allied Engineered Plastic). Twenty-four hours before the experiments began, cells were maintained in serumfree Coon's Modified Ham's F12 medium. The intracellular free $\mathrm{Ca}^{2+}$ concentration $\left(\left[\mathrm{Ca}^{2+}\right]_{\mathrm{i}}\right.$ ) was determined using the $\mathrm{Ca}^{2+}$ sensitive dye fura-2, as reported by Baldi and Dunn (1991). Cells were loaded with $1 \mu \mathrm{mol}$ fura-2 acetoxymethylester $1^{-1}$ for $40 \mathrm{~min}$ at $37^{\circ} \mathrm{C}$ in serum-free Coon's Modified Ham's F12 medium. The permeable acetoxymethylester of fura- 2 is hydrolysed by cellular esterases on entering the cells, and the fura-2 formed is relatively impermeable and becomes trapped inside the cells.

The monolayers of myometrial cells were then washed and incubated for a further $20 \mathrm{~min}$ in fura-2-free medium at $37^{\circ} \mathrm{C}$. Coverslips were mounted in a quartz cuvette with $2 \mathrm{ml}$ Krebs-Henseleit Hepes buffer $(\mathrm{KHH})$, containing $130 \mathrm{mmol}$ $\mathrm{NaCl} \mathrm{l}^{-1}, 5 \mathrm{mmol} \mathrm{KCl}{ }^{-1}, 1.25 \mathrm{mmol} \mathrm{CaCl}_{2} \mathrm{l}^{-1}, 0.8 \mathrm{mmol}$ $\mathrm{MgSO}_{4} \mathrm{l}^{-1}, 5.5 \mathrm{mmol}$ glucose $\mathrm{l}^{-1}, 20 \mathrm{mmol}$ Hepes $\mathrm{l}^{-1}$ ( $\mathrm{pH} 7.4$ ) and $0.1 \%$ fatty-acid-free BSA (pH 7.4), and maintained at $37^{\circ} \mathrm{C}$.
Fluorescence was measured using a single wavelength spectrofluorometer (University of Pennsylvania Biomedical Group, PA) set at $340 \mathrm{~nm}$ excitation with emission at $510 \mathrm{~nm}$. Fluorescence measurements were converted to values of $\left[\mathrm{Ca}^{2+}\right]_{i}$ by determining maximal fluorescence $\left(F_{\max }\right)$ with $60 \mu \mathrm{mol}$ ionomycin $\mathrm{l}^{-1}$ followed by minimal fluorescence $\left(F_{\min }\right)$

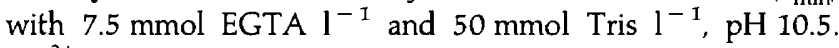
$\left[\mathrm{Ca}^{2+}\right]_{\mathrm{i}}$ was calculated according to the method of Grynkiewicz et al. (1985) using the 340:380 nm. Autofluorescence by the cells or peptides and leakage of fura- 2 outside the cells were negligible.

\section{Analysis of experimental results}

The binding data were evaluated quantitatively with nonlinear least squares curve fitting using the computer program LIGAND (Munson and Rodbard, 1980). Weighting was used based on the assumption of constant percentage error in bound ligand concentrations. This analysis provides optimal estimates of 'binding parameters' (such as affinity constants, binding capacities and nonspecific binding) for any number of ligands reacting simultaneously with any number of classes of site. The program provides objective measures of goodness of fit, in terms of both magnitude and randomness of residuals. It provides objective criteria for distinguishing between models of different complexity, using an F test based on the 'extrasum-of squares' principle (Munson and Rodbard, 1980).

The computer program ALLFIT (De Lean et al., 1978) was used for the analysis of sigmoidal dose-response curves obtained in binding studies and in measurements of $\left[\mathrm{Ca}^{2+}\right]_{\mathrm{i}}$. This program uses the constrained four-parameter logistic model to obtain estimates of $\mathrm{ED}_{50}$ and $\mathrm{IC}_{50}$ values, the logit-log slope ('pseudo-Hill coefficient') and relative potencies. Each data point represents the mean $\pm \mathrm{SE}$.

\section{Results}

\section{Binding studies of oxytocin antagonists}

The neurohypophysial hormone receptors in the uteri of pregnant humans and rabbits were identified pharmacologically by constructing complete sets of self- and crossdisplacement curves among $\left[{ }^{3} \mathrm{H}\right]$ oxytocin, $\left[{ }^{3} \mathrm{H}\right] \mathrm{AVP}$, $\left[{ }^{3} \mathrm{H}\right] \mathrm{d}\left(\mathrm{CH}_{2}\right)_{5}$ TyrMeAVP, the corresponding unlabelled peptides and the oxytocin antagonists. Experiments were conducted once in pooled membranes from the myometrium of pregnant women, and once in pooled membranes from the myometrium of pregnant rabbits. Computer modelling of experimental results was performed as described by Maggi et al. (1988b, 1990, 1991b, 1992). Quantitative analysis using the LIGAND program (Munson and Rodbard, 1980) indicated that a model consisting of only one binding site class was insufficient in both the human and rabbit uterus. Instead, a model with two binding site classes was required to give a satisfactory fit in rabbit myometrium $(P<0.0001)$, while a model with three binding site classes was needed to fit results from the human myometrium $(P<0.001)$.

A complete set of competition curves in the myometrium from pregnant women is shown in Fig. 1 . Tables 1 and 2 

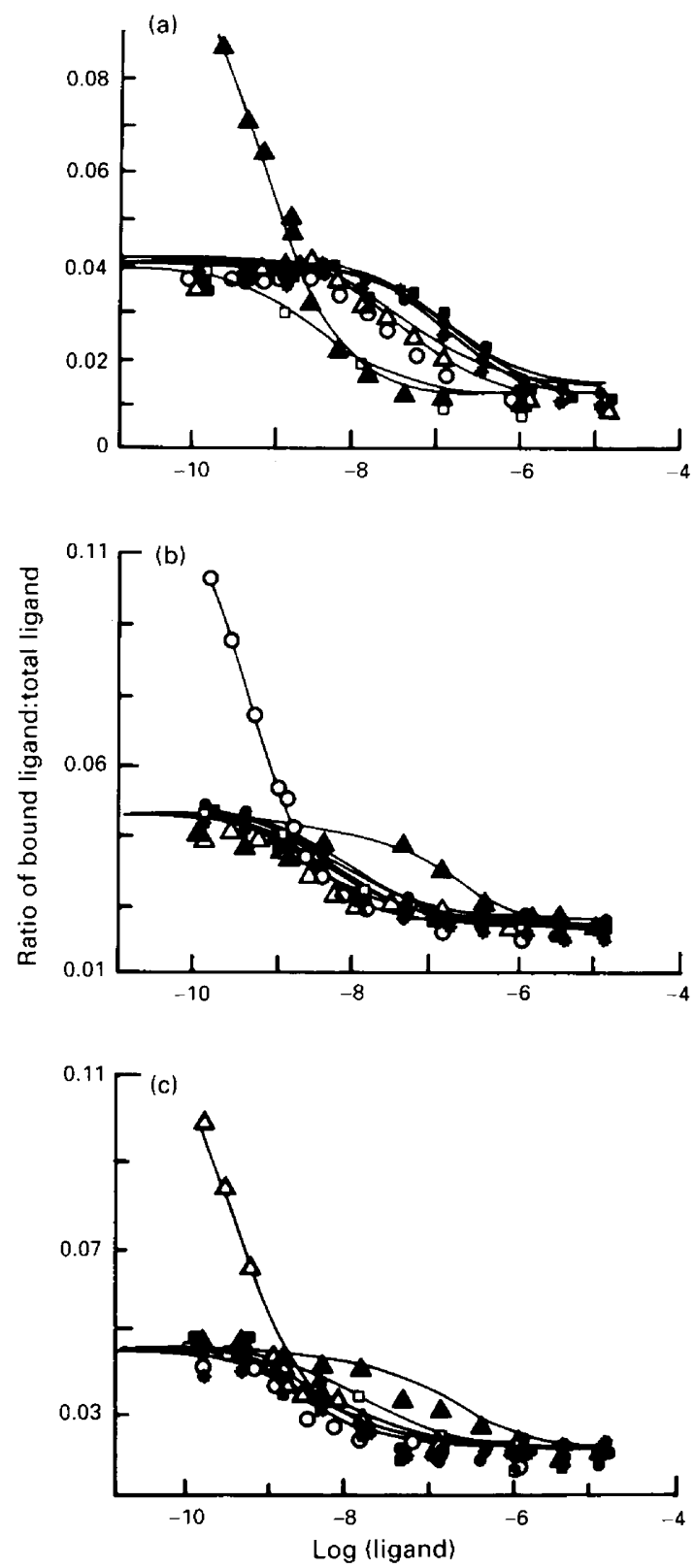

Fig. 1. Families of self- and cross-displacement curves between oxytocin $(\Delta)$, arginine vasopressin $(0), \mathrm{d}\left(\mathrm{CH}_{2}\right)_{5}$ TyrMeAVP $(\triangle),\left[\mathrm{Mpa}^{\mathrm{T}}\right.$,

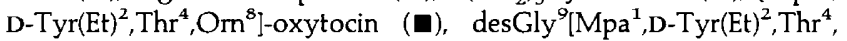
Orn ${ }^{8}$-oxytocin (*), desGly ${ }^{9}\left[\mathrm{D}-\mathrm{Tyr}(\mathrm{Et})^{2}, \mathrm{Thr}^{4}, \mathrm{Om}^{8}\right]$-dC6-oxytocin (-) and $\mathrm{d}\left(\mathrm{CH}_{2}\right)_{5}\left[\mathrm{Tyr}(\mathrm{Me})^{2}, \mathrm{Thr}^{4}, \mathrm{Orn}^{8}, \mathrm{Tyr}^{9}-\mathrm{NH}_{2}\right]$-vasotocin ( $\left.\square\right)$. The results shown in this figure are derived from one experiment using pooled membranes prepared from the myometrium of pregnant women. These curves were generated using the computer program LIGAND. The ratio of bound ligand:total ligand for (a) $\left[{ }^{3} \mathrm{H}\right]$ oxytocin, (b) $\left[^{3} \mathrm{H}\right]$ arginine vasopressin and $(c)\left[{ }^{3} \mathrm{H}\right] \mathrm{d}\left(\mathrm{CH}_{2}\right)_{5}$ TyrMeAVP is plotted against the total concentration of the varying ligand [ligand]; that is, labelled plus unlabelled ligand for homologous displacement curves, or unlabelled ligand alone for the heterologous competition curves. In homologous competition curves, the concentrations of the tracers were progressively reduced to give the optimum characterization of the high-affinity region of the binding curves. In the heterologous competition curves, fixed $\left(0.7 \mathrm{nmol} \mathrm{l^{-1 }}\right)$ concentrations of tracer were displaced by increasing concentrations of unlabelled ligands. Smooth curves show the predicted relationships for the three-site model shown in Table 1 . present binding parameters of ligands in the myometrium of pregnant humans and rabbits, respectively. In human myometrium, oxytocin binds with high affinity (0.18$\left.0.79 \mathrm{nmol} \mathrm{l}^{-\mathrm{I}}\right)$ to an apparent heterogeneity of sites $\left(R_{1}\right.$ sites, which can be divided into $R_{1 a}$ and $R_{1 b}$ sites). $R_{1 b}$ sites bind 10 times more oxytocin than do $R_{1 a}$ sites and show selectivity for oxytocin. However, the $\mathrm{R}_{\mathrm{Ia}}$ site is not selective for oxytocin but also binds arginine vasopressin with high affinity, as does the oxytocin receptor identified in rabbits. At present, the functional significance of this heterogeneity of oxytocin receptors in the human myometrium is unclear. However, these results add support to those of Kimura et al. (1992), who reported multiple hybridizing bands when human myometrium at term was probed with a cDNA specific for the oxytocin receptor.

In the myometrium of pregnant rabbits and humans another distinct subtype of neurohypophysial hormone receptor was identified that probably corresponds to the $\mathrm{VI}$ vasopressin receptor described in the uterus (Maggi et al., 1988b, 1990, 1991a, 1992). This site $\left(R_{2}\right)$ binds arginine vasopressin and the VI antagonist $\mathrm{d}\left(\mathrm{CH}_{2}\right)_{5}$ TyrMeAVP with relative selectivity.

The oxytocin antagonists tested, including OTA, dETVT, F123 and F327, are relatively selective for the oxytocin receptor in rabbit myometrium but not in human myometrium. In humans dETVT, F123 and F327 bind with higher affinity to the $\mathrm{VI}$ vasopressin receptor than to the oxytocin receptor, with affinity constants similar to those obtained for the VI antagonist $\mathrm{d}\left(\mathrm{CH}_{2}\right)_{5}$ TyrMeAVP. This finding is in agreement with a previous observation of Pettibone et al. (1992) that although these antagonists are selective for the oxytocin receptor in the rabbit uterus, they have higher affinities for the VI vasopressin receptor in humans.

To test the hypothesis that the oxytocin antagonists counteract the biological effect of oxytocin in the human uterus, we studied human myometrial cells obtained from the American Type Culture Collection (Hs 805.Ut), and prepared from normal cyclic women undergoing hysterectomy in the late luteal or early follicular phase of the menstrual cycle. These cells bind $\left[{ }^{125}\right.$ IJOTA as a function of time. The maximal specific binding of $0.1 \mathrm{nmol}\left[{ }^{125} \mathrm{I}\right] \mathrm{OTA}{ }^{-1}$ was obtained after $60 \mathrm{~min}$ at $22^{\circ} \mathrm{C}$ (data not shown). Under these experimental conditions myometrial cells express high concentrations of the oxytocin receptor (Table 3). To purify myometrial cells further from eventual fibroblast contamination, we selected oxytocinreceptor-positive and desmin-positive clones.

Mathematical modelling of $\left[{ }^{125}\right.$ I]OTA binding data indicates that a single class of binding site is present in human myometrial cells in culture, which is similar to the $R_{1 b}$ subtype of oxytocin receptor binding site present in myometrium of pregnant women (Fig. 2 and Table 3). In contrast, the presence of V1 vasopressin receptors in human myometrial cells could not be verified in this experiment. This finding could be related to the loss of specialized properties by isolated cells grown in vitro owing to the absence of appropriate inducers or to the presence of inhibitors. Williams et al. (1992) reported that in rat aortic vascular smooth muscle cells glucose specifically inhibits the expression of both angiotensin II and V1 vasopressin receptors. We could not detect any specific binding of angiotensin II in our preparation of myometrial cells. However, since we were particularly interested in the oxytocin receptor and 
Table 1. Concentration of receptors $\left(B_{\max }\right)$ and affinity constants $\left(K_{d}\right)$ for oxytocin $(O T)$, arginine vasopressin (AVP), $\mathrm{d}\left(\mathrm{CH}_{2}\right)_{5} \mathrm{TyrMeAVP}, \mathrm{d}\left(\mathrm{CH}_{2}\right)_{5}\left[\mathrm{Tyr}(\mathrm{Me})^{2}, \mathrm{Thr}^{4}, \mathrm{Orn}^{8}, \mathrm{Tyr}^{9}-\mathrm{NH}_{2}\right]$-vasotocin (OTA), $\left[\mathrm{Mpa}^{1}, \mathrm{D}-\mathrm{Tyr}(\mathrm{Et})^{2}, \mathrm{Thr}^{4}, \mathrm{Orn}^{8}\right]$-oxytocin (dETVT), desGly ${ }^{9}\left[\mathrm{Mpa}^{1}, \mathrm{D}-\mathrm{Tyr}\left(\mathrm{Et}^{2}\right)^{2}, \mathrm{Thr}^{4}, \mathrm{Orm}^{8}\right]$-oxytocin (F123) and desGly ${ }^{9}\left[\mathrm{D}-\mathrm{Tyr}(\mathrm{Et})^{2}, \mathrm{Thr}^{4}, \mathrm{Or}^{8}\right]$-dC6-oxytocin (F327) in the myometrium of pregnant women

\begin{tabular}{|c|c|c|c|c|c|c|}
\hline \multirow{3}{*}{$\begin{array}{l}\text { Parameter } \\
\mathrm{B}_{\max }\left(\mathrm{fmol} \mathrm{mg}^{-\mathrm{I}}\right)\end{array}$} & \multicolumn{6}{|c|}{ Binding site } \\
\hline & \multicolumn{2}{|r|}{$\mathrm{R}_{\mathrm{Ia}}$} & \multicolumn{2}{|r|}{$\mathrm{R}_{1 \mathrm{~b}}$} & \multicolumn{2}{|r|}{$\mathrm{R}_{2}$} \\
\hline & $25.6 \pm$ & 8.4 & $200.4=$ & \pm 22.04 & 110 & \pm 5.5 \\
\hline \multicolumn{7}{|l|}{$K_{\mathrm{d}}\left(\mathrm{nmol} !^{-1}\right)$} \\
\hline OT & $0.18 \pm$ & 0.18 & 0.79 & \pm 0.22 & 35 & \pm 8.4 \\
\hline AVP & $1.8 \pm$ & $\pm \quad 1.4$ & $13.7=$ & \pm 3.3 & 0.26 & \pm 0.034 \\
\hline $\mathrm{d}\left(\mathrm{CH}_{2}\right)_{5}$ TyrMeAVP & $621 \pm$ & \pm 714 & 14.2 & \pm 3.55 & 0.3 & \pm 0.037 \\
\hline OTA & $6.05 \pm$ & $\pm \quad 7.55$ & 0.66 & \pm 0.24 & 2.6 & \pm 0.86 \\
\hline dETVT & $110 \pm$ & \pm 124 & $41:$ & \pm 12 & 0.4 & \pm 0.1 \\
\hline F123 & 66 & $\pm \quad 79.2$ & 34 & \pm 10 & 0.5 & \pm 0.1 \\
\hline F327 & 1400 & \pm 1624 & 40 & \pm 12 & 0.6 & \pm 0.2 \\
\hline
\end{tabular}

Binding parameters and SEs were obtained from computer modelling of a self- and cross-competition study among $\left[{ }^{3} \mathrm{H}\right] \mathrm{OT},\left[{ }^{3} \mathrm{H}\right] \mathrm{AVP}$, $\left[{ }^{3} \mathrm{H}\right] \mathrm{d}\left(\mathrm{CH}_{2}\right)_{5}$ TyrMeAVP, the corresponding unlabelled peptides and the oxytocin antagonists.

Table 2. Concentration of receptors $\left(B_{\max }\right)$ and affinity constants $\left(K_{d}\right)$ for oxytocin (OT), arginine vasopressin (AVP), $\mathrm{d}\left(\mathrm{CH}_{2}\right)_{5} \mathrm{TyrMeAVP}, \mathrm{d}\left(\mathrm{CH}_{2}\right)_{5}\left[\mathrm{Tyr}(\mathrm{Me})^{2}, \mathrm{Thr}^{4}, \mathrm{Orn}^{8}, \mathrm{Tyr}^{9}-\mathrm{NH}_{2}\right]-$ vasotocin (OTA), [Mpa $\left.{ }^{1}, \mathrm{D}-\mathrm{Tyr}(\mathrm{Et})^{2}, \mathrm{Thr}^{4}, \mathrm{Orn}^{8}\right]$-oxytocin (dETVT), desGly ${ }^{9}\left[\mathrm{Mpa}^{1}, \mathrm{D}-\mathrm{Tyr}(\mathrm{Et})^{2}, \mathrm{Thr}^{4}, \mathrm{Orn}^{8} \mathrm{]}\right.$-oxytocin (F123) and desGly ${ }^{9}\left[\mathrm{D}-\mathrm{Tyr}(\mathrm{Et})^{2}, \mathrm{Thr}^{4}, \mathrm{Om}^{8}\right]-\mathrm{dC} 6$-oxytocin $(\mathrm{F} 327)$ in the myometrium of pregnant rabbits

\begin{tabular}{|c|c|c|c|c|}
\hline \multirow[b]{2}{*}{ Parameter } & \multicolumn{4}{|c|}{ Binding site } \\
\hline & \multicolumn{2}{|r|}{$\mathrm{R}_{1}$} & \multicolumn{2}{|r|}{$\mathrm{R}_{2}$} \\
\hline $\mathrm{B}_{\max }\left(\mathrm{fmol} \mathrm{mg^{-1 }}\right)$ & 180 & \pm 9.0 & 357 & \pm 18 \\
\hline \multicolumn{5}{|l|}{$K_{\mathrm{d}}\left(\mathrm{nmol} 1^{-1}\right)$} \\
\hline OT & 0.4 & $I \pm 0.053$ & 103.5 & \pm 16 \\
\hline AVP & 1.0 & \pm 0.20 & 0.5 & \pm 0.061 \\
\hline $\mathrm{d}\left(\mathrm{CH}_{2}\right)_{5}$ TyrMeAVP & 9.7 & $7 \pm 8.4$ & 0.13 & \pm 0.016 \\
\hline OTA & 0.0 & $5 \pm 0.02$ & 8.7 & \pm 1.7 \\
\hline dETVT & 6 & \pm 1.5 & 42.5 & \pm 6.4 \\
\hline $\mathrm{F}_{123}$ & 4.5 & \pm 1.1 & 30 & \pm 4.5 \\
\hline F327 & 7 & \pm 1.7 & 23 & \pm 3.45 \\
\hline
\end{tabular}

Binding parameters and SEs were obtained from computer modelling of a selfand cross-competition study among $\left[{ }^{3} \mathrm{H}\right] \mathrm{OT},\left[{ }^{3} \mathrm{H}\right] \mathrm{AVP},\left[{ }^{3} \mathrm{H}\right] \mathrm{d}\left(\mathrm{CH}_{2}\right)_{5} \mathrm{Tyr} \mathrm{Me}$ AVP, the corresponding unlabelled peptides and the oxytocin antagonists.

not in the VI vasopressin receptor, the loss of VI vasopressin receptors in these myometrial cells was not investigated further.

High concentrations of oxytocin receptors were found in the myometrial cells $\left(500 \mathrm{fmol}\right.$ per $10^{6}$ cells). The density of oxytocin receptors was further enriched in the cloned myometrial cells $\left(2940 \mathrm{fmol}\right.$ per $10^{6}$ cells; Table 3$)$. In the cloned cells, more than $90 \%$ of the total $\left[{ }^{125}\right.$ I]OTA added was specifically bound, while nonspecific binding was negligible $(2 \%)$. Hence, this cloned preparation of human myometrial cells in culture represents an ideal tool to investigate the function of the oxytocin receptor. The activity of dETVT on the oxytocininduced increase in $\left[\mathrm{Ca}^{2+}\right]_{i}$ in human myometrial cell preparations was therefore studied. Since the ligand specificity of the oxytocin receptor present in different preparations of myometrial cells was very similar, results obtained in different cell cultures were pooled.

\section{Effect of oxytocin antagonists on $\left[\mathrm{Ca}^{2+}\right]_{i}$ mobilization}

The basal $\left[\mathrm{Ca}^{2+}\right]_{\mathrm{i}}$ in fura-2-loaded myometrial cells was $102.2 \pm 3.8 \mathrm{nmol} \mathrm{I}^{-1}(n=68)$; addition of oxytocin induced an immediate initial transient increase of $\left[\mathrm{Ca}^{2+}\right]_{\mathrm{i}}$, reaching a peak within $30 \mathrm{~s}$. Figure $3 \mathrm{a}$ shows the result of a typical doseresponse experiment. The effect of oxytocin was dose dependent with an $\mathrm{EC}_{50}$ value of $2.5 \pm 0.5 \mathrm{nmol} \mathrm{I}^{-1}(n=3)$. Thus, to test the antagonistic properties of dETVT on oxtocin-induced $\left[\mathrm{Ca}^{2+}\right]_{i}$ mobilization, cells were stimulated with $3 \mathrm{nmol}$ oxytocin $\mathrm{I}^{-1}$. This concentration of oxytocin stimulated an increase of $\left[\mathrm{Ca}^{2+}\right]_{\mathrm{i}}$ to $350.7 \pm 48 \mathrm{nmol} \mathrm{l^{-1 }}(n=9)$. As shown in Fig. $3 \mathrm{~b}$, pretreatment with an increasing concentration of dETVT progressively blunted the effect of $3 \mathrm{nmol}$ oxytocin $1^{-1}$. The analysis using the program ALLFIT (De Lean $e t$ al., 1978) of results from five separate experiments indicates a mean $\mathrm{IC}_{50}$ value of $4.9 \pm 1.1 \mathrm{nmol} 1^{-1}$ and a slope factor not significantly different from unity, again suggesting the interaction of dETVT with a homogeneous class of receptor in myometrial cells.

\section{Discussion}

These results add support to previous evidence that the ligand specificity of neurohypophysial hormone receptors shows consistent interspecies variability. For example, dVDAVP is a selective agonist for the rat (Manning et al., 1973) and human (Maggi et al., 1989) V2 vasopressin receptors, but shows low 
Table 3. Concentration of receptors $\left(B_{\max }\right)$ and affinity constants $\left(K_{d}\right)$ for oxytocin $(O T)$, arginine vasopressin (AVP), d $\left(\mathrm{CH}_{2}\right)_{5}$ TyrMeAVP, $\mathrm{d}\left(\mathrm{CH}_{2}\right)_{5}\left[\mathrm{Tyr}(\mathrm{Me})^{2}, \mathrm{Thr}^{4}, \mathrm{Orn}^{8}, \mathrm{Tyr}^{9}-\mathrm{NH}_{2}\right.$ ]-vasotocin (OTA), $\left[\mathrm{Mpa}^{\mathrm{T}}, \mathrm{D}-\mathrm{Tyr}(\mathrm{Et})^{2}, \mathrm{Thr}^{4}, \mathrm{Orn}^{8}{ }^{8}\right.$-oxytocin (dETVT), desGly $\left[\mathrm{Mpa}^{1}, \mathrm{D}-\mathrm{Tyr}(\mathrm{Et})^{2}, \mathrm{Thr}^{4}, \mathrm{Orn}^{8}{ }^{8}\right.$-oxytocin (F123) and desGly ${ }^{9}\left[\mathrm{D}-\mathrm{Tyr}(\mathrm{Et})^{2}, \mathrm{Thr}^{4}, \mathrm{Orn}^{8}\right]$-dC6-oxytocin (F327) in different preparations of human myometrial cells

\begin{tabular}{|c|c|c|c|c|c|}
\hline Parameter & $\mathrm{M}_{\mathrm{I}}$ & Hs805.Ut & $\mathrm{M}_{2}$ & $D_{6}$ & Mean \\
\hline $\begin{array}{l}\mathrm{B}_{\max } \\
\quad\left(\mathrm{fmol} \text { per } 10^{6} \text { cells }\right)\end{array}$ & 532 & 592 & 360 & 2940 & \\
\hline \multicolumn{6}{|l|}{$K_{\mathrm{d}}\left(\mathrm{nmol} \mathrm{l}^{-1}\right)$} \\
\hline OT & 0.55 & 0.68 & 0.39 & - & $0.54 \pm 0.069$ \\
\hline AVP & 25.5 & 10.7 & 11.5 & - & $15.9 \pm 3.9$ \\
\hline $\mathrm{d}\left(\mathrm{CH}_{2}\right)_{5}$ TyrMeAVP & 9.4 & 8.4 & - & 5.8 & $7.9 \pm 0.86$ \\
\hline OTA & 0.34 & 0.32 & 0.2 & 0.2 & $0.26 \pm 0.032$ \\
\hline dETVT & 17.52 & 15.5 & 7.8 & 7.3 & $12 \pm 2.25$ \\
\hline F123 & - & - & - & 7.1 & 7.1 \\
\hline F327 & - & - & - & 7.7 & 7.1 \\
\hline
\end{tabular}

Binding parameters were obtained from computer modelling of homologous and heterologous competition curves between $\left.{ }^{[25} \mathrm{I}\right]$ OTA and several neurohypophysial hormones and analogues, using the program LIGAND (Munson and Rodbard, 1980). Values obtained in separate preparations of myometrial cells from two women (M1 and M2), in myometrial HS 805.Ut cells and in the cloned myometrial cells (D6) are shown.

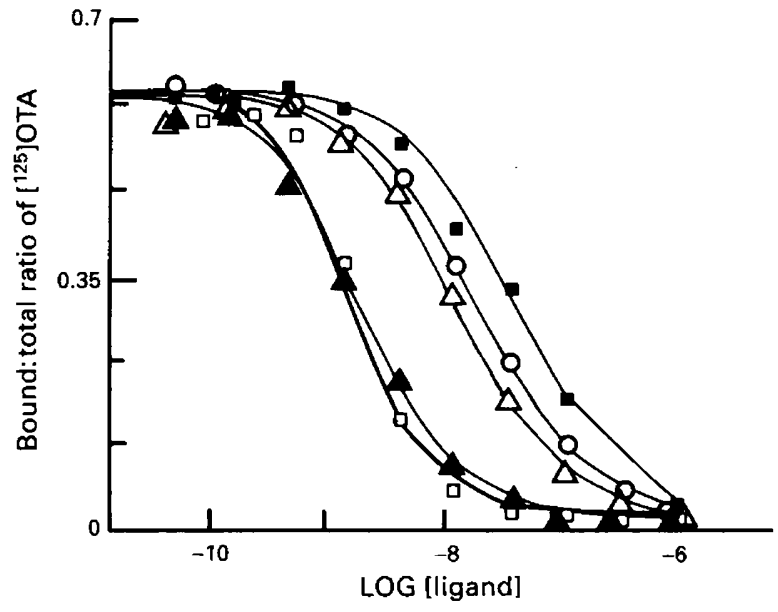

Fig. 2. Family of competition curves between oxytocin $(\mathbf{\Delta})$, arginine vasopressin (O), d( $\left(\mathrm{CH}_{2}\right)_{5}$ TyrMeAVP $(\triangle),\left[\mathrm{Mpa}^{\mathrm{I}}, \mathrm{D}-\mathrm{Tyr}(\mathrm{Et})^{2}, \mathrm{Thr}^{4}\right.$, Orn $\left.{ }^{8}\right]$ oxytocin (a) and $\mathrm{d}\left(\mathrm{CH}_{2}\right)_{5}\left[\mathrm{Tyr}(\mathrm{Me})^{2}, \mathrm{Thr}^{4}, \mathrm{Orn}^{8}, \mathrm{Tyr}^{9}-\mathrm{NH}_{2} \mathrm{I}_{-}\right.$ vasotocin ( $\square$ ) in Hs 805.Ut myometrial celis. These curves were generated by the program LIGAND. The ratio of bound $d\left(\mathrm{CH}_{2}\right)_{5}$ $\left[\right.$ Tyr $\left.\left.(\mathrm{Me})^{2}, \mathrm{Thr}^{4}, \mathrm{Orn}^{8},{ }^{125} \mathrm{I}\right] \mathrm{Tyr}^{9}-\mathrm{NH}_{2}\right]$-vasotocin ([ $\left.\left.{ }^{125} \mathrm{I}\right] \mathrm{OTA}\right):$ total ligand is plotted against the total concentration of the varying ligand [ligand]; that is labelled plus unlabelled ligand for homologous displacement curves, or unlabelled ligand alone for the heterologous competition curves. Smooth curves show the predicted relationships for the one-site model shown in Table 3.

affinity for the $\mathrm{V} 2$ vasopressin receptors present in porcine renal medulla (Maggi et al., 1986, 1988a). In addition, OTA is a selective antagonist for the rat (Elands et al., 1988) and rabbit (Maggi et al., 1991a) oxytocin receptor, but the same compound is less selective in humans (Maggi et al., 1990).

From this study, dETVT and two related oxytocin antagonists (F123 and F327) are selective for oxytocin receptors in the rabbit uterus, but not in the human uterus. In the human myometrium, these antagonists bind with high affinity to the
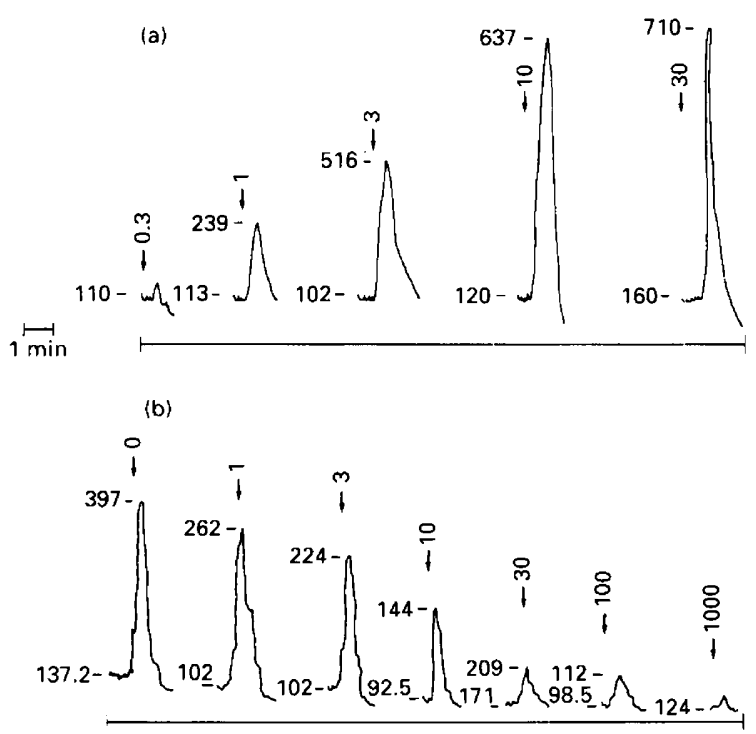

Fig. 3. Representative tracing of waveforms of the intracellular $\mathrm{Ca}^{2+}$ concentration $\left(\left[\mathrm{Ca}^{2+}\right]_{\mathrm{i}}\right)$ evoked by different concentrations of (a) oxytocin or (b) $\left[\mathrm{Mpa}^{1}, \mathrm{D}-\mathrm{Tyr}(\mathrm{Et})^{2}, \mathrm{Thr}^{4}, \mathrm{Orn}^{8}\right]$-oxytocin (dETVT) in human myometrial cells. Human myometrial cell monolayers grown on Aclar coverslips were loaded with fura-2 and incubated in Krebs-Henseleit Hepes buffer, pH 7.4. Basal $\left[\mathrm{Ca}^{2+}\right]_{i}$ was measured fluorometrically after reaching thermal equilibrium at $37^{\circ} \mathrm{C}$. In (b) coverslips were incubated for 2 min with the indicated concentration of dETVT and then stimulated with $3 \mathrm{nmol}$ oxytocin $\mathrm{I}^{-1}$. The arrows indicate the addition of the indicated nanomolar concentrations of peptides. Numbers on the ordinate axis indicate $\left[\mathrm{Ca}^{2+}\right]_{i}\left(\mathrm{nmol} \mathrm{l}{ }^{-1}\right)$.

V1 vasopressin receptor. This is in agreement with a previous radioligand binding study (Pettibone et al., 1992) and with the finding that dETVT antagonizes in vivo the vasopressininduced uterine contractility in nonpregnant women (Akerlund et al., 1986; Hauksson et al., 1988). Although originally developed for the treatment of primary dysmenorrhoea 
(Akerlund, 1987), clinical studies indicate that dETVT is effective in inhibiting uterine activity in patients with uncomplicated preterm labour (Akerlund et al., 1987; Andersen et al., 1987; Akerlund, 1991). This suggests (1) that VI vasopressin receptors might be involved in stimulating uterine contractions under these conditions, or (2) that at the concentrations used in clinical studies this antagonist effectively blocks oxytocin receptors, thereby inhibiting the effects of oxytocin in the myometrium.

The first hypothesis is in agreement with the previous identification of a VI vasopressin receptor in the myometrium of nonpregnant and pregnant humans (Maggi et al., 1990, 1992). However, the uterine concentration of this receptor is relatively constant during reproductive life, irrespective of the hormonal milieu or the stage of the pregnancy. Since labour is not affected in patients with diabetes insipidus (Hendricks, 1954) and the circulating concentration of arginine vasopressin does not change during parturition (De Vane and Porter, 1980), it is unlikely that the VI vasopressin receptor actively participates in the onset or progression of human labour. Nevertheless, the possibility that the VI vasopressin receptor could play a role in some pathological conditions such as fetal stress (Maggi et al., 1990) cannot be ruled out.

Concerning the second hypothesis, the present study indicates that as the concentration of dETVT increases, it binds to and blocks the activity of the human oxytocin receptor more effectively. Indeed, this antagonist inhibits the oxytocininduced $\left[\mathrm{Ca}^{2+}\right]_{i}$ mobilization in human myometrial cells in culture. Since in vitro these cells express a high concentration of oxytocin receptors but not of V1 vasopressin receptors, this effect is apparently mediated by blocking the oxytocin receptor. It is therefore possible that the effect of dETVT in preventing pre-term labour observed in clinical studies is due to its interaction with the oxytocin receptor. When this antagonist is given as a bolus injection i.v. $\left(10 \mathrm{nmol} \mathrm{l}^{-1} \mathrm{~kg}^{-1}\right.$ body mass) to humans, it reaches high concentrations $\left(85 \mathrm{nmol} \mathrm{1}{ }^{-1}\right.$; Lundin et al., 1986); in high nanomolar concentrations our in vitro study indicates that dETVT completely blocks the oxytocin receptor and the oxytocin-induced $\left[\mathrm{Ca}^{2+}\right]_{i}$ mobilization.

In conclusion, these results indicate that $\mathrm{dETVT}$ and related oxytocin antagonists preferentially bind to the V1 vasopressin receptor present in the human uterus. However, they also interact with the oxytocin receptor and block oxytocin-induced $\left[\mathrm{Ca}^{2+}\right]_{i}$ mobilization. The high affinity of dETVT for the VI vasopressin uterine receptor may represent an unexpected benefit for the relaxation of the uterus in pregnant and nonpregnant humans in view of the presence of biologically active VI vasopressin receptors in the myometrium.

\section{References}

Akerlund M (1987) Can primary dysmenorrhoea be alleviated by a vasopressin antagonist? Acta Obstetricia et Gynecologica Scandinava 66 459-461

Akerlund M (1991) Mechanisms by which vasopressin induces pain of primary dysmenorrhoea and the use of vasopressin and oxytocin antagonists in the management of primary dysmenorrhoea and preterm labour. In Vasopressin, pp. 339-347 Eds S Jard and R Jamison. Colloque INSERM/John Libbey Eurotext, Montrouge

Akerlund M, Hauksson A, Lundin S, Melin P and Trojnar J (1986) Vasotocin analogues which competitively inhibit vasopressin stimulated uterine activity in healthy women British Joumal of Obstetrics and Gynaecology 93 22-27

Akerlund M, Stromberg P, Hauksson A, Andersen LF, Lyndrup J, Trojnar J and Melin P (1987) Inhibition of uterine contractions of premature labour with an oxytocin analogue: results from a pilot study British Journal of Obstetrics and Gynaecology 94 1040-1044

Andersen LF, Lyndrup J, Akerlund M and Melin P (1987) Oxytocin receptor blockade: a new principle in the treatment of preterm labour? American Journal of Perinatology 6 196-199

Baldi E and Dunn MJ (1991) Endothelin binding and receptor downregulation in rat glomerular mesangial cell Journal of Pharmacology and Experimental Therapeutics 257 581-586

Casey ML and MacDonald PC (1988) Biomolecular processes in the initiation of parturition: decidual activation Clinical Obstetrics and Gynecology 31 533-552

Ciarochi FF, Robinson AG, Verbalis JG, Seif SM and Zimmerman EA (1985) Isolation and localization of neurophysin-like proteins in the rat uterus Peptides $6903-911$

De Lean A, Munson PJ and Rodbard D (1978) Simultaneous analysis of families of sigmoidal curves: application to bioassay, radioligand assay, and physiological dose-response curves American Journal of Physiology 235 E97-102

De Vane GW and Porter JC (1980) An apparent stress-induced release of arginine vasopressin in human neonates Journal of Clinical Endocrinology and Metabolism 51 1412-1416

Elands J, Barberis $\mathrm{C}_{\text {, Jard }} \mathrm{S}$, Tribollet E, Dreifuss JJ, Bankowski K, Manning $\mathrm{M}$ and Sawyer WH (1988) ${ }^{125}$ I-labelled $\mathrm{d}\left(\mathrm{CH}_{2}\right)^{5},\left[\mathrm{Tyr}(\mathrm{Me})^{2}, \mathrm{Thr}^{4}, \mathrm{Om}^{8}, \mathrm{Tyr}^{9}-\mathrm{NH}_{2}\right]-$ vasotocin: a selective oxytocin receptor ligand European Journal of Pharmacology 147 197-207

Fuchs AR and Fuchs F (1984) Endocrinology of human parturition: a review British Joumal of Obstetrics and Gynaecology 91 948-967

Fuchs AR, Vangsted A, Ivanisevic M and Demarest K (1987) Oxytocin antagonist (dTVT) and oxytocin receptors in myometrium and decidua American Journal of Perinatology 6 205-208

Fuchs F and Stakemann G (1960) Treatment of threatened premature labour with large doses of progesterone American Joumal of Obstetrics and Gynaecology 79 172-176

Grynkiewicz G, Poenie M and Tsien RY (1985) A generation of $\mathrm{Ca}^{++}$ indicators with greatly improved fluorescence properties Journal of Biological Chemistry $2603440-3450$

Hauksson A, Akerlund M and Melin P (1988) Uterine blood flow and myometrial activity at menstruation, and the action of vasopressin and a synthetic antagonist British Journal of Obstetrics and Gynaecology 95 898-904

Hendricks CH (1954) Neurohypophysis in pregnancy Obstetric Gynecology Survey 9 323-341

Hixon JE and Flint APF (1987) Effects of a luteolytic dose of oestradiol benzoate on uterine receptor concentrations, phosphoinositide turnover and prostaglandin $\mathrm{F}_{2 \mathrm{a}}$ secretion in sheep Journal of Reproduction and Fertility $\mathbf{7 9}$ $457-463$

Kimura T, Tanizawa O, Mori K, Brownstein MJ and Okayama H (1992) Structure and expression of a human oxytocin receptor Nature 356 526-529

Leake RD (1990) Oxytocin in the initiation of labour. In Uterine Function: Molecular and Cellular Aspects, pp 361-371 Eds ME Carsten and JD Miller. Plenum Press, New York.

Lefebvre DL, Giaid A, Bennet H, Lariviere R and Zing HH (1992) Oxytocin gene expression in rat uterus Science 256 1553-1556

Leoni P, Carli F and Halliday D (1990) Intermediate filaments in smooth muscle from pregnant and non-pregnant human uterus Biochemical Journal 269 31-34

Lundin S, Akerlund M, Fagerstrom P-O, Hauksson A and Melin P (1986) Pharmacokinetics in the human of a new synthetic vasopressin and oxytocin uterine antagonist Acta Endocrinologica 112 465-472

Maggi M, Kassis S, Malozowski S, Guardabasso G and Rodbard D (1986) Identification and characterization of a vasopressin isoreceptor in porcine seminal vesicles Proceedings of the National Academy of Sciences USA 83 8824-8828

Maggi M, De Rossi M, Genazzani AD, Rodbard D and Serio M (1988a) Similarity of vasopressin receptors in seminal vesicles and renal medulla of pigs Journal of Reproduction and Fertility 84 401-407

Maggi M, Genazzani AD, Giannini S, Torrisi C, Baldi E, Di Tommaso M, Munson PJ, Rodbard D and Serio M (1988b) Vasopressin and oxytocin 
receptors in vagina, myometrium, and oviduct of rabbits Endocrinology 122 2970-2980

Maggi M, Baldi E, Genassani AD, Giannini S, Natali A, Rodbard D, Costantini A and Serio $\mathbf{M}$ (1989) Vasopressin receptors in human seminal vesicles: identification, pharmacological characterization and comparison with the vasopressin receptors present in human kidney Journal of Andrology 10 393-400

Maggi M, Del Carlo P, Fantoni G, Giannini S, Torrisi C, Casparis D, Massi GB and Serio M (1990) Human myometrium during pregnancy contains and responds to V1 vasopressin receptors as well as oxytocin receptors Joumal of Clinical Endocrinology and Metabolism 70 1142-1154

Maggi M, Peri A, Giannini S, Fantoni G and Serio M (1991a) Oxytocin and V1 vasopressin receptors in rabbit endometrium during pregnancy Journal of Reproduction and Fertility 91 575-581

Maggi M, Vannelli GB, Peri A, Brandi ML, Fantoni G, Giannini S, Torrisi C, Guardabasso V, Barni T, Toscano V, Massi GB and Serio M (1991b) Immunolocalization, binding, and biological activity of endothelin in rabbit uterus: effect of ovarian steroids. American Journal of Physiology 260 E292-305

Maggi M, Magini A, Fiscella A, Giannini S, Fantoni G, Toffoletti F, Massi and Serio M (1992) Sex steroid modulation of neurohypophysial hormone receptors in human nonpregnant myometrium Journal of Clinical Endocrinology and Metabolism 74 385-395
Manning M, Balaspiri L, Acosta M and Sawyer WH (1973) Solid phase synthesis of I-deamino,4-valine-8-D-arginine-vasopressin (DVDAVP), a highly potent and specific antidiuretic agent possessing protracted effects Journal of Medical Chemistry 16 975-978

Munson PJ and Rodbard D (1980) LIGAND: a versatile computerized approach for characterization of ligand-binding systems Analytical Biochemistry 107 220-239

Nissenson R, Flouret G and Hechter O (1978) Opposing effects of estradiol and progesterone on oxytocin receptors in rabbit uterus Proceedings of the National Academy of Sciences USA 75 2044-2048

Pettibone DJ, Kishel MT, Woyden CJ, Clineschmidt BV, Bock MG, Freidinger RM, Veber DF and Williams D (1992) Radioligand binding studies reveal marked species differences in the vasopressin V1 receptor of rat, rhesus and human tissues Life Science 50 1953-1958

Sawyer WH and Manning M (1989) Experimental uses of neurohypophysial hormone analogs Trends in Endocrinology and Metabolism 2 48-50

Soloff MS (1975) Uterine receptor for oxytocin: effects of estrogen Biochemical and Biophysical Research Communication 65 205-212

Steer PJ (1990) The endocrinology of parturition in humans Bailliere's Clinical Endocrinology and Metabolism 4 333-349

Williams B, Tsai P and Schrier RW (1992) Glucose-induced downregulation of angiotensin II and arginine vasopressin receptors in cultured rat aortic vascular smooth muscle cells Joumal of Clinical Investigation 90 1992-1999 